\title{
MSANTD3 Gene
}

National Cancer Institute

\section{Source}

National Cancer Institute. MSANTD3 Gene. NCI Thesaurus. Code C158458.

This gene may be involved in protein complex formation or DNA binding. 